\title{
Od filozofie $k$ historické sociologii a zpět. Rozhovor s Jóhannem Pállem Árnasonem (krátký dovětek)
}

\author{
BOHUSLAV ŠALANDA - JIŘÍ ŠUBRT
}

Zajímavě jsi nastínil všechny kontexty, souvislosti a návaznosti. Domníváme se, že by byla namístě určitá tečka, popř́padě dvojtečka Všechno není uzavřeno, takový výhled či perspektiva $v$ naší vědní oblasti by vưbec nebyla marná.

Nejdříve pár slov k vlastním projektům. Napsal jsem během loňského léta a minulého zimního semestru knihu s titulem „The Labyrinth of Modernity - Horizons, Pathways and Mutations“, která má letos vyjít u Rowman \& Littlefield, v rámci série spojené s časopisem Social Imaginaries. Je to pokus o systematičtější výklad modernity jako nové civilizace, se specifickým důrazem na problematiku komunismu jako nejvýraznější alternativní modernity ve dvacátém století. Měla by následovat další kniha o základech a pojmosloví civilizační analýzy, něco jako krátký, koncizní a aktualizovaný úvod. Pak se uvidí. Ale co se týče obecných vyhlídek a úkolů civilizační analýzy, dalo by se uvést větší množství témat; tady se však omezím na jeden zvlášt klíčový komplex problémů. Diagnózy doby mají ted’ velkou konjunkturu, hlavně v souvislosti s chmurnými představami o budoucnosti (budiž uznáno, že nikoliv bezdůvodnými). V tomto kontextu se často mluví o nastalém rozkladu nebo možném kolapsu civilizace, at už evropské nebo obecněji definované, ale bez dalšího pojmového upřesnění. Bylo by záhodno dostat do této debaty náležitě vypracovanou civilizačně-analytickou perspektivu. A to se týká - jak to ted’ vidím - hlavně dvou tematických okruhů. Jednak potřebujeme civilizační pohled na geopolitiku či mezinárodní vztahy (druhý výraz je trochu matoucí, protože odráží anglosaskou záměnu států s národy), a to v mnohem diferencovanější verzi než tomu bylo u Huntingtona, jehož kniha o střetu civilizací byla vlastně medvědí službou - dělala civilizacím negativní reklamu. Nebylo od té doby napsáno mnoho relevantních prací o této tematice, ale za zmínku stojí kniha Petera Katzensteina, Civilizations in World Politics - A Plural and Pluralist Perspective, vydána $\mathrm{v}$ roce 2009. A za druhé by se civilizacionisté více zajímat o ekologii a ekologické dějiny, a vůbec o mezisvět mezi přírodními a společenskými vědami. V té souvislosti bych na konec chtěl upozornit na česko-kanadského autora, který sice v České republice není neznámý, ale rozhodně by si zasloužil širší zájem. Václav Smil působil dlouho na University of Manitoba a napsal asi čtyřicet knih (první český překlad vyšel až v roce 2013). Jedná se o mezioborový prrístup zakotvený v přírodních vědách, ale dvě poslední knihy Energy and Civilization, 2017, a Growth: From Microorganisms to Megacities, 2019 - mají významné styčné body s tematikou společenských věd, a v neposlední řadě se srovnávacím studiem civilizací.

DOI: $10.14712 / 23363525.2020 .23$ 